\title{
PENGARUH pH LARUTAN PENGEKSTRAK TERHADAP RENDEMEN DAN KARAKTERISTIK PEKTIN ALBEDO KULIT BUAH DURIAN
}

\author{
Effect of pH on The Yield and Charaterisctics of Pectin Extracted from The Albedo of Durian \\ Rind
}

\begin{abstract}
Alexander Nathanael Yusuf ${ }^{1)}$, Nengah Kencana Putra ${ }^{2)}$, I Ketut Suter ${ }^{2)}$
${ }^{1}$ Mahasiswa Program Studi Ilmu dan Teknologi Pangan, Fakultas Teknologi Pertanian, Universitas Udayana

${ }^{2}$ Dosen Program Studi Ilmu dan Teknologi Pangan, Fakultas Teknologi Pertanian, Universitas Udayana

Kampus Bukit Jimbaran, Badung-Bali
\end{abstract}

\begin{abstract}
The purposes of this research is to determine the effect of $\mathrm{pH}$ solution during extraction of pectin from the albedo of durian rind on its characteristic and yield resulted from the extraction which resulted with the highest amount of yield and best pectin characteristic. This research is using Randomized Block Design (RBD) with the treatment of the $\mathrm{pH}$ solution during the extraction with the $\mathrm{pH}$ being used is $(2.0 ; 2.5 ; 3.0 ; 3.5$ and 4.0$)$. . The treatment is repeated three times so that were obtained 15 unit of experiment and data were analyzed by variance analysis. If any effect showed by the treatment then the analysis were followed by the Duncan test. The test result indicate that the $\mathrm{pH}$ of the solution have an effect to the yield and characteristic of pectin extracted from the albedo of durian rind. The treatment that produce pectin with the best characteristic and the most yield are obtained at solution with $\mathrm{pH} 2.0$ with the result of yield $(4.07 \%)$, equivalent weight $(767.39 \mathrm{mg})$ level of metoksil $(10.06 \%)$, ash content $(4.67 \%)$. And levels of anhidrogalacturonat acid $(84.04 \%)$
\end{abstract}

Keywords: $p H$, pectin, fruit peel durian, albedo

\section{PENDAHULUAN}

Durian (Durio zibethinus murr.) yang dijuluki The King of Fruit merupakan salah satu buah yang sangat popular di Indonesia. Buah yang memiliki rasa dan aroma yang khas ini sangat digemari oleh sebagian banyak orang. Rasa buahnya yang manis dan aroma harum buahnya menjadi daya tarik tersendiri bagi pencinta durian. Warna daging buahnya bervariasi, ada yang berwarna putih, kuning, dan oranye serta buah ini dilengkapi dengan adanya kandungan kalori, vitamin, lemak, dan protein, akan tetapi kurang dalam hal pemanfaatannya. Selama ini, bagian buah durian yang lebih umum dikonsumsi adalah bagian salut buah atau dagingnya. Jika dilihat kegunaan durian ternyata bukan hanya daging buahnya yang dapat dimanfaatkan, tetapi apabila digali lebih dalam lagi dapat ditemukan berbagai manfaat dari semua bagian pohon buah durian tersebut, (Purnomosidhi dkk., 2007). Akan tetapi pada kenyataannya bagian kulit durian selama ini dibuang begitu saja tanpa dimanfaatkan terlebih dahulu, padahal apabila dilihat buah durian memiliki presentase daging yang cukup rendah yaitu hanya sekitar 20-35\%, sedangkan kulit (60-75\%), dan biji (5-15\%) belum termanfaatkan secara maksimal (Prasetyaningrum, 2010). Albedo atau kulit bagian dalam durian merupakan salah satu limbah buah durian dan tidak memiliki nilai ekonomi. Kulit Durian secara proporsional mengandung unsur selulosa yang tinggi (50$60 \%)$ dan kandungan lignin (5\%) serta kandungan pati yang rendah (5\%) sehingga dapat diindikasikan bahan tesebut dapat digunakan dalam pembuatan pektin (Frandy, 2013).

Korespondensi Penulis :

E-mail : alexander_nathanael@yahoo.com ${ }^{1)}$ 
Pektin merupakan bahan yang digunakan dalam pengolahan pangan yang bernilai tinggi serta berguna secara luas dalam pembentukan gel dan bahan penstabil pada produk sari buah, nilai ekonomis pektin sebenarnya cukup tinggi, akan tetapi pengolahan untuk produksi pektin di Indonesia sampai hari ini masih kurang (Cempaka, 2010). Kebutuhan pektin di Indonesia sendiri mulai meningkat dengan bertambahnya industri - industri dalam bidang pengolahan dan makanan makanan Menurut BPS (2013), Indonesia mengimpor pektin sebanyak 200 ton pada tahun 2013 Sumber pektin yang utama adalah sayurmayur dan buah-buahan. Pektin terdapat pada dinding sel semua jaringan tanaman yang berfungsi sebagai zat perekat interseluler. Kandungan pektin yang lebih tinggi terdapat pada sel-sel tanaman yang masih aktif dalam pertumbuhannya, seperti akar muda, buah dan daun (Kertesz, 1951).

Produksi pektin di dalam bahan alami dapat dilakukan dengan proses ekstraksi. Ekstraksi adalah salah satu cara pemisahan satu atau lebih komponen-komponen dari suatu bahan yang merupakan sumber komponen bahan tersebut.Ekstraksi pektin dapat dilakukan dengan cara meghidrolisis protopektin dengan menggunakan asam. Faktor-faktor yang mempengaruhi ekstraksi pektin adalah lama ekstraksi, suhu ekstraksi dan $\mathrm{pH}$ dari médium. Ion $\mathrm{H}^{+}$pada asam berfungsi selain memecahkan ikatan protopektin dengan senyawa-senyawa dalam dinding sel albedo durian juga menyatukan satu molekul pektin dengan molekul pektin yang lain, sehingga terbentuk sebuah jaringan yang dapat memerangkap air (Constenla dan Lozano, 2003).

Rouse dan Crandall, (1978) menyatakan bahwa suhu yang digunakan pada ekstraksi pektin berkisar antara $70^{\circ} \mathrm{C}-100^{\circ} \mathrm{C}$, dengan lama waktu 20-60 menit, larutan yang digunakan mempunyai $\mathrm{pH}$ 1,4-2,6. Hilton dalam Suarya (1990) menyatakan bahwa pektin yang dihasilkan dengan ekstraksi pada suhu $100^{\circ} \mathrm{C}$ selama 30 menit pada $\mathrm{pH}$ 2,5-3,0 akan mengurangi kekuatan gel pektin, sedangkan jika diekstraksi pada suhu $85^{\circ} \mathrm{C}$ maka kekuatan gel akan tetap. (Ariasni 2009) menyatakan ekstraksi pektin ampas buah nangka dengan metode sulistiyawati et,al., (1992) pada suhu $85^{\circ} \mathrm{C}$ pada $\mathrm{pH} 1,5-3,5$ selama 5 jam memiliki karakteristik pektin terbaik pada $\mathrm{pH}$ 1,5 dengan perbandingan pelarut dan bahan baku 1:5 .Berdasarkan hal tersebut di atas pada penelitian ini diteliti pengaruh $\mathrm{pH}$ terhadap rendemen dan karakteristik pektin kulit buah durian.

\section{METODE PENELITIAN}

Bahan baku yang digunakan pada penelitian adalah albedo kulit buah durian yang sudah matang, aquades, bahan kimia yang digunakan, $\mathrm{NaOH}, \mathrm{HCL}$, alkohol 95\%, phenolptalein dan phenol red. Proses produksi pektin dalam penelitian ini berdasarkan pada Sulistyawati, et al (1992) yang telah dimodifikasi dengan tahap-tahap sebagai berikut: Kulit albedo buah durian yang sudah matang dipotong atau dibelah, kemudian diblender dan dihancurkan. Hancuran kulit buah durian selanjutnya ditambah dengan larutan pengekstrak yaitu larutan aquades yang telah diasamkan dengan HCL sehingga pH-nya menjadi sesuai dengan perlakuan $(2,0 ; 2,5 ; 3,0 ; 3,5$ dan 4,0), dengan perbandingan bahan baku : larutan pengekstrak (1: 5) (b/v), dan waktu pemanasan \pm 5 jam dengan suhu $90^{\circ} \mathrm{C}$ Setelah ekstraksi selesai, dilakukan penyaringan dengan kain kasa sebanyak dua lapis. Filtrat yang diperoleh diendapkan dengan alkohol 95 $\%$ dengan rasio $1: 1(\mathrm{v} / \mathrm{v})$ selama \pm 1 jam. Untuk memisahkan endapan dengan cairan, dilakukan penyaringan dengan kain kasa yang dirangkap dua, residu yang diperoleh selanjutnya dikeringkan dalam oven dengan suhu $50^{\circ} \mathrm{C}( \pm 12 \mathrm{jam})$. Endapan yang sudah kering dihancurkan dan diayak dengan 
menggunakan ayakan 60 mesh sehingga

\section{HASIL DAN PEMBAHASAN}

Hasil penelitian menunjukan bahwa $\mathrm{pH}$ larutan pengekstrak memberikan pengaruh

Tabel 1 Pengaruh pH Larutan Pengekstrak diperoleh pektin

terhadap rendemen, berat equivalent, kadar metoksil, kadar abu, dan kadar asam anhidrogalakturonat seperti yang terlihhat pada Tabel 1.

\begin{tabular}{llllll}
\hline & \multicolumn{5}{c}{$\mathrm{pH}$ Larutan Pengekstrak } \\
\cline { 2 - 6 } & $2,0(\mathrm{P} 1)$ & $2,5(\mathrm{P} 2)$ & $3,0(\mathrm{P} 3)$ & $3,5(\mathrm{P} 4)$ & $4,0(\mathrm{P} 5)$ \\
\hline Rendemen (\%) & $4,07 \pm 0,00 \mathrm{a}$ & $1,10 \pm 0,00 \mathrm{c}$ & $1,19 \pm 0,04 \mathrm{~b}$ & $1,16 \pm 0,00 \mathrm{~b}$ & $1,18 \pm 0,01 \mathrm{~b}$ \\
Berat Equivalent & $767,39 \pm 0,00 \mathrm{e}$ & $781,18 \pm 1,52 \mathrm{~d}$ & $855,61 \pm 2,52 \mathrm{c}$ & $915,71 \pm 7,20 \mathrm{~b}$ & $986,02 \pm 3,04 \mathrm{a}$ \\
Kadar Metoksil (\%) & $10,06 \pm 0,00 \mathrm{~b}$ & $10,80 \pm 0,57 \mathrm{a}$ & $10,10 \pm 0,00 \mathrm{~b}$ & $10,51 \pm 0,00 \mathrm{ab}$ & $10,80 \pm 0,58 \mathrm{a}$ \\
Kadar Abu (\%) & $4,67 \pm 0,01 \mathrm{a}$ & $4,65 \pm 0,01 \mathrm{a}$ & $4,61 \pm 0,01 \mathrm{a}$ & $4,55 \pm 0,00 \mathrm{ab}$ & $4,42 \pm 0,16 \mathrm{~b}$ \\
Kadar Asam & $84,04 \pm 0,59 \mathrm{a}$ & $83,91 \pm 0,01 \mathrm{~b}$ & $82,73 \pm 0,00 \mathrm{c}$ & $82,02 \pm 0,00 \mathrm{~d}$ & $81,91 \pm 0,04 \mathrm{e}$ \\
Anhidrogalakturonat (\%) & & & & & \\
\hline
\end{tabular}

Keterangan: Huruf yang sama dibelakang nilai rata-rata pada kolom yang sama menunjukkan berbeda tidak nyata $(\mathrm{P}>0,05)$.

\section{Rendemen}

Hasil analisis menunjukkan bahwa perlakuan $\mathrm{pH}$ berpengaruh sangat nyata $(\mathrm{P}<0,01)$ terhadap rendemen pektin albedo kulit albedo buah durian. Nilai rata-rata rendemen pektin albedo kulit buah durian dapat dilihat pada Tabel 1. Tabel 1 menunjukan bahwa semakin tinggi $\mathrm{pH}$ larutan pengekstrak rendemen cenderung mengalami penurunan. Ekstraksi dengan $\mathrm{pH}$ 2,0 (P1) menghasilkan nilai rata-rata rendemen tertinggi 4,07\% dan rata-rata nilai rendemen terendah terdapat pada $\mathrm{pH} 2,5\left(\mathrm{P}_{2}\right)$ sebesar $1,10 \%$. Menurut Gusti, (2008) ekstraksi pektin dengan larutan $\mathrm{pH}$ rendah proses hidrolisis protopektin menjadi pektin terjadi lebih intensif sehingga menghasilkan rendemen yang lebih tinggi. Pektin yang merupakan polisakarida yang kompleks komposisinya sangat bervariasi tergantung dari sumber dan kondisi yang digunakan pada saat ekstraksi sehingga konsentrasinya yang dihasilkan dapat berbeda (Christensen, 1984).

\section{Berat Equivalent}

Hasil analisis ragam menunjukkan bahwa perlakuan $\mathrm{pH}$ pelarut berpengaruh sangat nyata $(\mathrm{P}<0,05)$, terhadap berat equivalen pektin albedo kulit buah durian.
Nilai rata-rata berat equivalen pektin dapat dilihat pada Tabel 1. Berat equivalen menunjukkan derajat polimerisasi pektin. Tabel 1 menunjukan berat equivalen pektin hasil ekstraksi dari kulit albedo buah durian berkisar antara 767,39 sampai dengan 986,08. Semakin meningkat $\mathrm{pH}$ maka berat equivalen akan semakin tinggi. Menurut Kencana (2010) hal ini terjadi karena pada pH cairan pengekstrak yang lebih rendah terjadi fragmentasi molekul pektin sehingga berat molekulnya menjadi lebih rendah. Penurunan berat molekul inilah yang menyebabkan berat equivalent ikut menurun. Menururt IPPA (International Pectin Producer Association) standar berat equivalen pektin adalah 600-800 ( Roikah, dkk 2016).

\section{Kadar Metoksil}

Hasil analisis ragam menunjukkan bahwa perlakuan $\mathrm{pH}$ larutan pengekstrak berpengaruh nyata $(\mathrm{P}<0,05)$ terhadap kadar metoksil pektin albedo kulit durian. Kadar metoksil menunjukkan banyaknya gugus metil ester pada molekul pektin, kadar metoksil berpengaruh pada sifat pektin seperti waktu pembentukan gel dan kemampuan mengikat gula dan ion bivalen seperti $\mathrm{Ca}^{++}$ dalam pembentukan gel (Whistler and Daniel, 1985). Pada Tabel 1 terlihat bahwa nilai rata- 
rata kadar metoksil tertinggi pada $\left(\mathrm{P}_{5}\right)$ yaitu $10,81 \%$ dan nilai rata-rata kadar metoksil terendah diperoleh pada $\left(\mathrm{P}_{1}\right)$ yaitu $10,06 \%$ dianjutkan dengan $\left(\mathrm{P}_{3}\right) 10,10 \%$. Nilai tersebut menunjukkan bahwa pektin dari kulit albedo buah durian termasuk pektin bermetoksil tinggi (minimum 7\%) Menurut (Kertesz 1951) pektin bermetoksil tinggi dapat larut dalam air dingin apabila dilakukan pengadukan yang cukup sedangkan pektin bermetoksil rendah memerlukan panas untuk dapat larut dalam air.

\section{Kadar Abu}

Hasil analisis ragam menunjukkan bahwa $\mathrm{pH}$ pelarut berpengaruh nyata $(\mathrm{P}<0.05)$ terhadap kadar abu pektin albedo kulit durian. nilai rata-rata kadar abu terendah diperoleh pada perlakuan $\mathrm{pH}$ 4,0 $\left(\mathrm{P}_{5}\right)$ yaitu sebesar $4,42 \%$, dan terbesar pada perlakuan $\mathrm{pH} 2,0$ $\left(\mathrm{P}_{1}\right)$ sebesar $4,67 \%$ ini menunjukan bahwa Kadar abu pada pektin semakin menurun seiring dengan meningkatnya $\mathrm{pH}$, hal ini disebabkan karena kemampuan asam untuk melarutkan mineral alami dari bahan akan meningkat dengan meningkatnya konsentrasi asam.mineral yang terlarut akan ikut mengendap bercampur dengan pektin pada saat pengendapan dengan alkohol (Kalapathy dan Proctor, 2001). Menurut (Hwang dkk., 1992) semakin rendah kadar abu pada pektin maka semakin tinggi pula tingkat kemurnian dari pektin itu sendiri. Menururt IPPA (International Pectin Producer Association) standar kadar abu pektin pektin adalah maksimum 10\% ( Roikah, dkk 2016).

\section{Kadar Asam Anhidrogalakturonat}

Hasil analisis ragam memperlihatkan bahwa perlakuan $\mathrm{pH}$ larutan penggekstrak berpengaruh sangat nyata terhadap kadar asam anhidrogalakturonat pectin albedo kulit buah durian $(\mathrm{P}<0.01)$ Nilai rata-rata kadar asam anhidrogalakturonat pektin terendah diperoleh dari perlakuan $\mathrm{pH} 4,0(\mathrm{P} 5)$ sebesar $81,91 \%$. Sedangkan pada $\mathrm{pH} \quad 2,0$ (P1) menghasilkan rata-rata kadar asam anhidrogalaturonat tertinggi yaitu $84,04 \%$ dapat dilihat pada tabel 1 bahwa terjadi kecenderungn penurunan kadar asam anhidrogalaturonat dengan menaiknya nilai pH. Menurut (Constenta dan Lozano, 2003) hal ini disebabkan karena semakin tinggi konsentrasi asam maka akan semakin tinggi ion $\mathrm{H}^{+}$dimana ion $\mathrm{H}^{+}$berfungsi memecahkan ikatan protopektin dan juga menyatukan satu molekul pektin dengan molekul yang lain sehingga terbentuk struktur yang dapat menangkap air. Asam anhidrogalakturonat merupakan struktur dasar senyawa pektin (Fennema, 1985). Kadar asam anhidrogalakturonat menunjukkan tingkat kemurnian pektin, semakin tinggi kadar asam anhidrogalakturonat maka semakin tinggi pula mutu pektin tersebut. Pektin kasar pada umumnya mengandung asam anhidrogalakturonat minimum $20 \%$ (Kertesz, 1951). Menururt IPPA (International Pectin Producer Association) standar kadar asam anhidrogalakturonat pada pektin adalah minimum 35\%( Roikah, dkk 2016).

\section{KESIMPULAN}

Berdasarkan hasil penelitian yang telah dilakukan dapat diambil kesimpulan sebagai berikut:

1. Larutan pengekstrak dengan $\mathrm{pH}$ yang berbeda berpengaruh tehadap rendemen, kadar abu, berat equivalent, kadar metoksil, dan kadar asam anhidrogalakturonat pektin kulit buah durian.

2. Larutan pengekstrak dengan $\mathrm{pH} 2,0$ menghasilkan pektin dengan rendemen tertinggi $(4,075 \%)$, dan karakteristik terbaik dengan hasil berat equivalent (767,39), kadar metoksil $(10,06 \%)$, kadar abu $(4,67 \%)$ dan kadar asam anhidrogalakturonat $(84,07 \%)$ 


\section{DAFTAR PUSTAKA}

Anderson, 1W. dan Wen-Ju Lin Chen. 1979. Plant Fiber, Carbohydrate and Lipid Metabolisme. Am. J. Clin. Nutr. 32: 246-63.

Ariasni N. L. P. E, 2009. Pengaruh pH Larutan Pengekstrak dan Perbandingan Ampas Buah Nangka dengan Larutan Pengekstrak Terhadap Rendemen Serta Karakteristik Pektin. Fakultas Teknologi Pertanian Universitas Udayana, Denpasar.

Berk, Z. 1976. Introduction to The Biochemistry of Food. Elsevier Scientific Pulb. Co., Amsterdam.

BPS. 2013. Statistik Perdagangan Ekspor Impor Indonesia, diolah Pusdatin Perdagangan, Kementerian Perdangangan, Jakarta.

Christensen, S.H. 1984. Pectin. Martin Glicksman (Ed.). Food Hydrocolloids. CRC Press, Inc., Florida, p. 205-230.

Cempaka, A. 2010. Pektin. Makalah. Universitas Gadjah Mada, Yogyakarta.

Cohn, C. dan L. Cohn. 2001. The Byproducts of Fruit Processing, p. 225 - 247. In D. Arthey and P. R. Ashurt (ed.). Fruit Processing, Nutrition Products, and Quality Management. Aspen Publishers, Inc. Gaithersburg.

Constenla, D. dan J. E. Lozano, 2003, "Kinetic Model of Pectin

Kertesz, Z.I. 1951. The Pectic Substances. Interscience Publishers. New York
Demethylation", Latin American Applied Research 33: 91-96.- 396

Coulate, T. P. 1993. Food, The Chemistry of Its Components. The Royal Society of Chemistry, Cambridge. 325 p.

Fennema, O. R. 1985. Principles of Food Science. Marcel Dekker, Inc., New York.

Frandy 2013. Manfaat Kulit Durian. Universitas Muhamadiyah Malang: Malang.

Gusti, Nidya. 2009. Pengaruh pH dan Lama Ekstraksi Terhadapp Rendemen dan Mutu Pektin dari Kulit Kakao (Theobroma cacao, L). Universitas Anandalas:Padang.Skripsi

Hwang ,J., Roshdy, T.H., Kontominas, M. dan Kokini, J,L. (1992). Comparison of dialysis and metal precipitation effects on apple pectin. Journal of Food Science 47:1180-1184

Kalapathy, U. dan A. Proctor. 2001. Effect of Acid Extraction and Alcohol Precipitation Conditions on The Yield and Purity of Soy Hull Pectin. Food Chemistry $73: 393$

Kareer, P. 1950. Organic Chemistry Elsevier Publishing Company. Inc., New York, Amsterdam London Bruss

Kencana, P. N. 2010. Optimasi Proses Ekstraksi Pektin Dari Dami Buah Nangka (Artocapus Heterophyllus Lamk) Agritech, Vol 30. 
Prasetyaningrum, A 2010, Mekanisasi Proses Olahan Biji Durian Menjadi Produk Pangan Yang Kompetitif, Riptek, Vol.4, No.I1, Tahun 2010, Hal.: 47 52.

Purnomosidhi, P., Suparman, J. M. Roshetko, dan Mulawarman, 2007. Perbanyakan dan Budidaya BuahBuahan: durian, mangga, jeruk, melinjo, dan sawo. Pedoman Lapangan, Edisi Kedua. World Agroforestry Center \& Winrock Internasional, Bogor.

Ranganna, S. 1979. Manual of Analysis of Fruit and Vegetable Products. TataMc.Graw Hill, New Delhi.

Robinson, D. S. 1990. Food Biochemistry and Nutritional Value. Longman Scientific and Technical. John Wiley and Sons, Inc., New York.

Roikah S., Diyah P.R.W., Latifah dan Kusumastuti E. (2016) Ekstraksi dan karakterisasi Pektin Dari Belimbing Wuluh(Averroa Bilimbi,L)jurnal Bahan Alam Terbarukan 5(1) 29-36, Semarang.

Rouse, A. H. dan P. G. Crandall. 1978. Pectic content lime and lemon peel as extracted by nitric acid. J. Food Sci. 43 (1): $72-73$.

Sharma, B.R., L. Naresh, N.C. Dhuldhoya, S.U. Merchant dan U.C. Merchant. 2006. An overview on pectins. Times Food Processing Journal, June-July: $44-51$.
Suarya, B. 1990. Pengaruh Perlakuan pH Ekstraksi dan Konsentrasi Alkohol Pengendap Terhadap Jumlah dan Mutu Pektin Kering dari Kulit papaya. Tesis Fakultas Pertanian Universitas Katolik Widya Karya, Malang.

Sudarmadji, S; B. Haryono dan Suhardi. 1984. Prosedur Analisa untuk Bahan Makanan dan Pertanian. Liberty, Yogyakarta.

Sulistyawati, Djumari dan Unus. 1992. Optimasi kondisi ekstraksi pektin dari kulit buah kakao. Pelita Perkebunan 8 (2): 45 - 49.

Steel, R. G. D. dan J. H. Torrie. 1980. Principles and Procedures of Statistics. McGraw-Hill International Book Company, Singapore.

Suyitno. 1989. Petunjuk Labolatorium Rekayasa Pangan. PAU Pangan dan Gizi UGM, Yogyakarta.

Whistler, R. L. dan J. R. Daniel. 1985. Carbohydrate. In O. R. Fennema (Ed.). Food Chemistry. Marcel Dekker Inc., New York. pp. 70 125.

Yusuf, W. N. 2011. Proposal Penelitian Pengolahan Limbah Kulit Durian http://www.wigiwildanberbagi.com [20 April 2019] 